\title{
ANALISIS PENGARUH KESADARAN WAJIB PAJAK DAN PENGETAHUAN WAJIB PAJAK TERHADAP KEPATUHAN DALAM MEMBAYAR PAJAK KENDARAAN BERMOTOR (PKB) DI WILAYAH DKI JAKARTA
}

\author{
Mutiara Cendana \\ Sekolah Tinggi Ilmu Ekonomi Wiyatamandala \\ priscillamutiarac@gmail.com \\ Bayu Laksma Pradana \\ Sekolah Tinggi Ilmu Ekonomi Wiyatamandala \\ bayu@wym.ac.id
}

\begin{abstract}
This research was conducted with the aim of analyzing the effect of taxpayer awareness and taxpayer knowledge of taxpayer compliance in paying vehicle tax in DKI Jakarta, the independent variables in this research were taxpayer awareness and taxpayer knowledge, while the dependent variable was compliance taxpayer. This research was conducted using the Survey Research method using a questionnaire as a data collection. Sampling was done using the Simple Random Sampling method and then the data collected was analyzed by multiple linear regression. Regression test results in this research indicate that the independent variable partially has a positive effect but not significantly to the dependent variable while simultaneously the independent variable has a significant effect on the dependent variable, namely taxpayer compliance in paying vehicle tax in DKI Jakarta.
\end{abstract}

Keywords: Vehicle Taxpayer Compliance, Tax payer Awareness, Tax Knowledge.

\begin{abstract}
ABSTRAK
Penelitian ini dilakukan dengan tujuan untuk melakukan analisis pengaruh kesadaran wajib pajak dan pengetahuan wajib pajak terhadap kepatuhan wajib pajak dalam membayar pajak kendaraan bermotor di wilayah DKI Jakarta, variabel independen pada penelitian ini adalah kesadaran wajib pajak dan pengetahuan wajib pajak, sedangkan variabel dependennya adalah kepatuhan wajib pajak. Penelitian ini dilakukan menggunakan metode survey research dengan menggunakan kuesioner sebagai media pengumupulan data. Pengambilan sampel dilakukan dengan metode simple random sampling dan selanjutnya data yang telah dikumpulkan dianalisis dengan regresi linear berganda. Hasil uji regresi pada penelitian ini menunjukkan bahwa variabel independen secara partial berpengaruh positif namun tidak signifikan terhadap variabel dependen sedangkan secara simultan variabel independen berpengaruh signifikan terhadap variabel dependen, yakni kepatuhan wajib pajak dalam membayar pajak kendaraan bermotor di wilayah DKI Jakarta.
\end{abstract}


Kata Kunci: Kepatuhan Wajib Pajak Kendaraan Bermotor, Kesadaran Wajib Pajak, Pengetahuan Perpajakan.

\section{PENDAHULUAN}

Negara mempunyai kewajiban untuk memenuhi kepentingan rakyatnya dengan melaksanakan pemerintahan dan pembangunan Negara. Untuk memenuhi kepentingan rakyat pemerintah membutuhkan dana, dana tersebut dikumpulkan dari berbagai potensi sumber daya yang dimiliki negara, baik berupa kekayaan alam maupun dari penerimaan negera. Penerimaan negara sendiri terbagi menjadi penerimaan dalam negeri dan penerimaan luar negeri, dan pajak menjadi salah satu sumber penerimaan dalam negeri yang terbesar. Berdasarkan badan yang di lihat pemungutnya, pajak dibedakan menjadi pajak pusat dan pajak daerah. Pajak pusat merupakan pajak yang dikelola pemerintah pusat melalui Direktorat Jendral Pajak (DJP) yang menjadi sumber penerimaan negara di dalam APBN, sedangkan pajak daerah merupakan pajak yang dikelola pemerintah daerah yang menjadi sumber penerimaan daerah melalui Badan Pajak dan Retribusi Daerah (BPRD) di dalam APBD. Menurut (UndangUndang Republik Indonesia Nomor 32 Tahun 2004 Tentang Pemerintahan Daerah, 2004) tentang pemerintahan daerah bahwa dalam penyelenggaraan pemerintahan, pemerintah daerah yang mengatur dan mengurus sendiri urusan pemerintahan menurut asas otonomi dan tugas pembantuan. Dengan adanya peraturan tersebut pemerintah daerah diharapkan dapat mengatur keuangan daerah, salah satunya melalui penerimaan daerah, yakni pemungutan pajak daerah. Pemungutan pajak daerah diperoleh dari penerimaan pajak suatu daerah yang mana bila pertumbuhan ekonomi di daerah tersebut meningkat, maka akan dapat mempengaruhi pendapatan pajak daerah tersebut. Pajak daerah yang merupakan hak bagi pemerintah daerah, yang dapat digunakan untuk meningkatkan kemajuan daerah adalah Pajak Kendaraan Bermotor (PKB). Pajak Kendaraan Bermotor (PKB) merupakan komponen pajak yang memiliki kontribusi yang cukup 
tinggi dalam pendapatan daerah seiring dengan meningkatnya jumlah kendaraan bermotor di tiap daerah dari waktu ke waktu. Walaupun memiliki kontribusi yang cukup tinggi, pajak kendaraan bermotor belum memberikan nilai kontribusi

Tabel 1 Realisasi dan Anggaran PKB di DKI Jakarta

\begin{tabular}{cccccc} 
Tahun & $\begin{array}{c}\text { Jumlah Kendaraan } \\
\text { Terdaftar }\end{array}$ & APBD-P & Realisasi & $\%$ \\
\hline 2015 & 8.697 .064 & 6.050 .000 .000 .000 & 6.090 .200 .500 .774 & $100,7 \%$ \\
2016 & 9.105 .377 & 7.050 .000 .000 .000 & 7.143 .530 .355 .999 & $101,3 \%$ \\
2017 & 9.464 .077 & 7.900 .000 .000 .000 & 8.005 .898 .498 .574 & $101,3 \%$ \\
2018 & 9.876 .546 & 8.000 .000 .000 .000 & 8.552 .500 .495 .393 & $106,9 \%$ \\
\hline
\end{tabular}

Sumber : Badan Pajak dan Retribusi Daerah - DKI Jakarta

Dari tabel di atas digambarkan bahwa setiap tahunnya realisasi penerimaan PKB di Wilayah DKI Jakarta selalu melebihi anggaran yang sudah ditentukan oleh Pemerintah Daerah dengan persentase yang meningkat pada tahun 2018, yaitu sebesar 5,6\%. Namun nilai tersebut belum memberikan kontribusi yang diharapkan karena masih banyak wajib pajak yang belum melaksanakan kewajibannya dalam membayar pajak kendaraan bermotor. Sampai September 2019, jumlah wajib pajak yang masih belum membayarkan kewajibannya sebanyak 4.990.171 yang di yang diharapkan oleh pemerintah daerah. 
mendorong para wajib pajak itu sendiri untuk secara sadar melakukan pembayaran pajak tepat waktu serta melakukan pelaporan pajak dengan benar. Kesadaran tersebut juga harus disertai dengan adanya pengetahuan perpajakan yang berlaku. Kurangnya pengetahuan pajak yang ada di masyarakat menyebabkan munculnya ketidakpatuhan yang ada dalam membayar pajak. Berdasarkan

\section{TELAAH LITERATUR}

Definisi Pajak

Pajak adalah pungutan wajib yang dibayar rakyat kepada negara dan akan digunakan untuk kepentingan pemerintah dan masyarakat umum. Rakyat yang membayar pajak tidak akan merasakan manfaat dari pajak secara langsung, karena pajak digunakan untuk kepentingan umum, bukan untuk kepentingan pribadi. Pajak merupakan salah satu sumber dana pemerintah untuk melakukan pembangunan, baik pemerintah pusat maupun pemerintah daerah. Pemungutan pajak dapat dipaksakan karena dilaksanakan berdasarkan undang-undang.

Berdasarkan (Undang-Undang Republik Indonesia Nomor 28, 2007) pasal 1 ayat 1 , pengertian pajak adalah uraian latar belakang yang telah dipaparkan oleh karena itu peneliti termotivasi untuk melakukan penelitian mengenai kepatuhan pajak dengan judul "analisis pengaruh kesadaran wajib pajak dan pengetahuan wajib pajak terhadap kepatuhan dalam membayar pajak kendaraan bermotor (PKB) di wilayah DKI jakarta”.

kontribusi wajib kepada negara yang terutang oleh orang pribadi atau

badan yang bersifat memaksa berdasarkan undang-undang, dengan tidak mendapatkan imbalan secara langsung dan digunakan untuk keperluan negara bagi sebesarbesarnya kemakmuran rakyat.

Fungsi Pajak

1. Fungsi Anggaran (Budget air) Pajak berfungsi untuk membiayai pengeluaran- pengeluaran negara. Untuk menjalankan tugas-tugas rutin negara dan melaksanakan pembangunan, negara membutuhkan biaya.

2. Fungsi Mengatur (Regulerend) 
Pemerintah bisa mengatur pertumbuhan ekonomi melalui kebijaksanaan pajak untuk mencapai tujuan. Contohnya melindungi produksi dalam negeri, pemerintah menetapkan bea masuk yang tinggi untuk produk luar negeri.

3. Fungsi Stabilitas

Pemerintah memiliki dana untuk menjalankan kebijakan yang berhubungan dengan stabilitas harga sehingga inflasi dapat dikendalikan,

4. Fungsi Redistribusi Pendapatan Pajak yang dipungut oleh negara akan digunakan untuk membiayai semua kepentingan umum, termasuk untuk membiayai pembangunan sehingga dapat membuka kesempatan kerja, yang akan meningkatkan pendapatan masyarakat.

Pengelompokan Pajak

1. Sifat Pajak

Pajak Subjektif dalam pengenaannya yang mana memperhatikan keadaan atau kondisi pribadi wajib pajak (berstatus kawin atau tidak kawin, dan sebagainya).

\begin{abstract}
Sedangkan pajak objektif dalam pengenaannya hanya memperhatikan sifat obyek pajak tanpa dengan memperhatikan keadaan maupun kondisi wajib pajak bersangkutan. Contoh pajak objektif adalah pajak pertambahan nilai (PPN), Pajak Bumi dan Bangunan (PBB), dan Pajak Penjualan atas Barang Mewah (PPnBM).
\end{abstract}

2. Pihak Penanggung Pajak Pembayaran pajak langsung tidak dapat dialihkan kepada orang lain. Contohnya, seorang suami tidak dapat mengalihkan pajak yang menjadi tanggung jawabnya terhadap istri. Sedangkan pembayaran pajak tidak langsung dalam pelunasannya tidak harus dilunasi oleh wajib pajak, karena pajak tidak langsung diberlakukan pada objek pajak tertentu, bukan pada wajib pajak.

3. Pihak Pemungut Pajak Pajak Negara (Pajak pusat) merupakan pajak yang dipungut oleh pemerintah 
pusat dan digunakan untuk

membiayai seluruh

kebutuhan rumah tangga.

Dengan tujuan untuk

pemerataan penghasilan bagi

pemerintah daerah di

Indonesia. Pajak Daerah

merupakan salah satu sumber

pendapatan daerah (APBD)

yang penting untuk

membiayai pelaksanaan

pemerintahan daerah dan

pembangunan. Pajak

Kendaraan Bermotor

Berdasarkan (Peraturan

Daerah Provinsi Daerah

Khusus Ibukota Jakarta,

2015) tentang perubahan

Peraturan Daerah Nomor 8

Tahun 2010 tentang Pajak

Kendaraan Bermotor,

Kendaraan bermotor adalah

semua kendaraan beroda

berserta gandengannya yang

digunakan di semua jenis

jalan darat, yang digerakkan

oleh peralatan teknik berupa

motor atau peralatan lainnya

yang berfungsi untuk

mengubah suatu sumber daya

energi tertentu menjadi

tenaga bergerak kendaraan bermotor yang bersangkutan, termasuk alat berat dan alat besar yang dalam operasinya mengunakan roda dan motor yang tidak melekat secara permanen serta kendaran bermotor yang dioperasikan di air. Pajak Kendaraan

Bermotor, dipungut pajak atas kepemilikan dan/atau penguasaan kendaraan bermotor.

\section{Kepatuhan Wajib Pajak}

Kepatuhan wajib pajak merupakan suatu tindakan wajib pajak yang patuh dan taat terhadap kewajiban perpajakan sesuai dengan ketentuan perpajakan yang berlaku dengan keadaan semua kewajiban perpajakannya telah dipenuhi. Secara umum, kepatuhan wajib pajak dibagi dua, yaitu :

1. Kepatuhan formal adalah keadaan dimana wajib pajak memenuhi kewajiban dan patuh terhadap perpajakan sesuai dengan aturan formal perpajakan yang berlaku.

2. Kepatuhan Material adalah keadaan dimana wajib pajak 
memenuhi semua ketentuan material perpajakan.

Kesadaran Wajib Pajak

Kesadaran wajib pajak adalah suatu kondisi dimana wajib pajak mengetahui, mengakui, mengerti dan menaati ketentuan perpajakan yang berlaku serta memiliki kesungguhan dan keinginan untuk memenuhi kewajiban pajaknya. Pengetahuan wajib pajak pengetahuan wajib pajak merupakan pemahaman wajib pajak tentang perpajakan dan peraturan perundang-udangan yang berlaku,

yang menimbulkan adanya kesadaran wajib pajak dan meningkatkan nilai kepatuhan wajib pajak dalam membayar kewajiban pajak. Berdasarkan teori-teori yang telah dijabarkan, maka diperlukan kerangka pemikiran yang bertujuan mendeskripsikan alur hubungan variabel penelitian dapat digambarkan sebagai berikut :

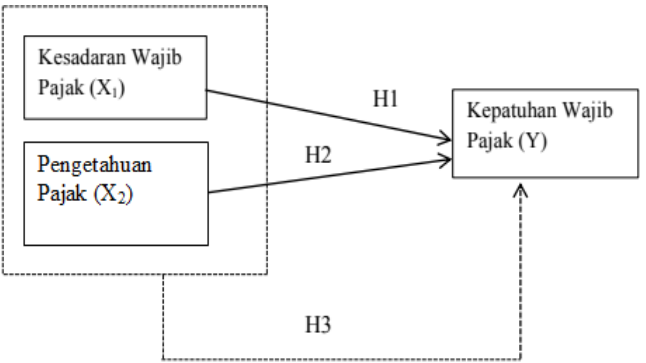

Gambar 1 Model Kerangka Pemikiran

Hipotesis yang dapat ditarik dari kerangka pemikiran di atas:

$\mathrm{H}_{1}$ : Kesadaran Wajib Pajak berpengaruh terhadap Kepatuhan Wajib Pajak dalam membayar pajak di Wilayah DKI Jakarta.

$\mathrm{H}_{2}$ : Pengetahuan Wajib Pajak berpengaruh terhadap
Kepatuhan Wajib Pajak dalam membayar pajak di Wilayah DKI Jakarta.

$\mathrm{H}_{3}$ : Kesadaran Wajib Pajak dan Pengetahuan Wajib Pajak secara simultan berpengaruh terhadap Kepatuhan Wajib Pajak dalam membayar pajak di Wilayah DKI Jakarta. 


\section{METODE PENELITIAN}

Metode penelitian yang digunakan dalam penelitian ini, menggunakan pendekatan kuantitatif dengan penelitian yang bersifat survey research. Menurut (Sugiyono, 2013) mengatakan bawha metode survey merupakan penelitian yang dilakukan dengan menggunakan angket sebagai alat penelitian yang dilakukan pada populasi besar maupun kecil, tetapi data yang dipelajari adalah data dari sampel yang diambil dari populasi tersebut sehingga ditemukan kejadian relatif, distribusi, dan hubungan antar variabel, sosiologis maupun psikologis. Dalam penelitian tersebut sampel yang diambil dengan menggunakan metode simple random sampling. Menurut (Sarjono \& Julianita, 2011) simple random sampling adalah cara pengambilan sampel secara acak dari anggota populasi tanpa mempedulikan tingkatan, dengan demikian penulis

\section{HASIL DAN PEMBAHASAN}

Uji Asumsi Klasik

Berdasarkan hasil uji validitas terhadap setiap variabel, dapat dijelaskan bahwa setiap variabel mengambil sampel penelitian dengan cara membagikan kuisioner yang dibuat menggunakan google forms kemudian disebarkan secara online melalui media online dan media sosial. Kuisioner tersebut disebarkan pada wajib pajak kendaraan bermotor yang memiliki kendaraan bermotor yang terdaftar pada kantor Samsat di wilayah DKI Jakarta dengan rentang usia wajib pajak yang diteliti, yaitu usia 18-45 tahun. Dalam penelitian ini, data-data yang berkaitan dalam penelitian ini diperoleh menggunakan data primer yang dibuat dan dirangkum oleh peneliti dari kuisioner yang telah disebarkan, dan data sekunder yang diperoleh dari peneliti sebelumnya yang melakukan penelitian terkait. Metode analisis data yang digunakan dalam penelitian ini adalah analisis regresi berganda. Tujuan penelitian dari penggunakan metode analisis ini adalah untuk mengetahui besarnya pengaruh variabel bebas (X) terhadap varibel terikat (Y).

yang terlibat dalam penelitian ini dapat dikatakan valid, karena nilai dari pearson correlation ( $\mathrm{r}$ hitung) berada di atas nilai $r$ table. 
Berdasarkan hasil uji realiabilitas dengan menggunakan alpha cronbach sebagai alat uji, maka dari variabel yang terlibat dalam penelitian dapat dikatakan reliabel karena memenuhi syarat, yakni nilai dari cronbach's alpha > 0,6 atau 60\%. Uji Asumsi Klasik Pada penelitian ini berdasarkan hasil pengujian yang telah dilakukan dapat dinyatakan data dalam penelitian ini sudah lolos dalam pengujian asumsi klasik yang diantaranya, yaitu uji normalitas, uji multikolinearitas, uji autokorelasi dan uji heteroskedastisitas.

Tabel 2 Hasil Uji F

\begin{tabular}{|c|c|c|c|c|c|c|}
\hline \multicolumn{7}{|c|}{ ANOVA $^{a}$} \\
\hline \multicolumn{2}{|l|}{ Model } & $\begin{array}{l}\text { Sum of } \\
\text { Squares }\end{array}$ & df & Mean Square & $\mathrm{F}$ & Sig. \\
\hline \multirow[t]{3}{*}{1} & Regression & 164.205 & 2 & 82.103 & 9.617 & $.000^{\mathrm{b}}$ \\
\hline & Residual & 520.795 & 61 & 8.538 & & \\
\hline & Total & 685.000 & 63 & & & \\
\hline
\end{tabular}

Berdasarkan hasil uji F, nilai Sig. pada penelitian ini menunjukkan nilai 0,000 dimana nilai ini $<0,05$. Dari nilai tersebut dapat disimpulkan bahwa pada penelitian ini variabel $\mathrm{X}$ dan variabel $\mathrm{Y}$ memiliki pengaruh yang signifikan dan menjadikan model penelitian ini fit. Yang menjelaskan bahwa pada penelitian ini $\mathrm{H}_{0}$ ditolak dan $\mathrm{Ha}$ diterima, yakni kesadaran wajib pajak dan pengetahuan wajib pajak secara simultan berpengaruh signifikan terhadap Kepatuhan Wajib Pajak dalam membayar kewajiban perpajakan.

Tabel 3 Hasil Uji T

\begin{tabular}{|c|c|c|c|c|c|c|}
\hline \multicolumn{7}{|c|}{ Coefficients $^{a}$} \\
\hline & & \multicolumn{2}{|c|}{ Unstandardized Coefficients } & \multirow{2}{*}{$\begin{array}{c}\text { Standardized } \\
\text { Coefficients } \\
\text { Beta }\end{array}$} & \multirow[b]{2}{*}{$\mathrm{t}$} & \multirow[b]{2}{*}{ Sig. } \\
\hline & & $\mathrm{B}$ & Std. Error & & & \\
\hline \multirow[t]{3}{*}{1} & (Constant) & 6.793 & 2.104 & & 3.229 & .002 \\
\hline & $\mathrm{x} 1$ & .231 & .157 & .226 & 1.473 & .146 \\
\hline & x2 & .336 & .169 & .306 & 1.994 & .051 \\
\hline
\end{tabular}

a. Dependent Variable: $\mathrm{y} 1$ 
Berdasarkan tabel di atas, maka dihasilkan persamaan regresi linear berganda sebagai berikut :

$\mathrm{Y}=6,793+0.231 \mathrm{X}_{1}+0,336 \mathrm{X}_{2}+\mathrm{e}$ Berdasarkan uji $\mathrm{T}$, nilai Sig. pada penelitian ini untuk variabel $\mathrm{X}_{1}$ menunjukkan nilai 0,146 dan untuk variabel $\mathrm{X}_{2}$ menunjukkan nilai 0,051 . Dari nilai tersebut dapat disimpulkan bahwa $\mathrm{X}_{1}$ sebesar 0,146>0,05 dan $\mathrm{X}_{2}$ sebesar $0,051>0,05$, kedua variabel independen memiliki pengaruh positif terhadap variabel dependen pada penelitian ini, yakni variabel kesadaran wajib pajak dan pengetahuan wajib pajak berpengaruh positif terhadap variabel kepatuhan wajib pajak. Namun kedua variabel $\mathrm{X}$ tidak berpengaruh signifikan terhadap variabel $\mathrm{Y}$ sehingga penelitian ini tidak mempunyai daya generalisasi karena tidak dapat diimplementasikan ke kasus lain yang sejenis.

$\mathrm{H}_{1}$ : kesadaran wajib pajak secara partial tidak berpengaruh signifikan terhadap kepatuhan wajib pajak.

Berdasarkan hasil uji $\mathrm{T}$ atau partial terhadap variabel kesadaran wajib pajak menampilkan hasil nilai Sig. pada variabel ini adalah 0,146 . Hal ini menunjukkan bahwa pada penelitian ini variabel yang diteliti menghasilkan $\mathrm{H}_{0}$ ditolak dan $\mathrm{Ha}$ diterima. Dari data ini, maka variabel Kesadaran Wajib Pajak secara partial berpengaruh positif namun tidak signifikan terhadap kepatuhan wajib pajak.

$\mathrm{H}_{2}$ : pengetahuan wajib pajak secara partial tidak berpengaruh signifikan terhadap kepatuhan wajib pajak.

Berdasarkan hasil uji t atau partial terhadap variabel pengetahuan wajib pajak menampilkan hasil nilai Sig. pada variabel ini adalah 0,051. Hal ini menunjukkan bahwa pada penelitian ini variabel yang diteliti menghasilkan $\mathrm{H}_{0}$ ditolak dan $\mathrm{Ha}$ diterima. Dari data ini, maka variabel pengetahuan wajib pajak secara partial berpengaruh positif namun tidak signifikan terhadap kepatuhan wajib pajak. 


\section{Tabel 4 Hasil Uji $R$ Square}

\section{Model Summary}

\begin{tabular}{ll|r|r|r} 
Model & $\mathrm{R}$ & R Square & \multicolumn{1}{c}{$\begin{array}{c}\text { Adjusted R } \\
\text { Square }\end{array}$} & $\begin{array}{c}\text { Std. Error of } \\
\text { the Estimate }\end{array}$ \\
\hline 1 & $.490^{\text {a }}$ & .240 & .215 & 2.922 \\
\hline
\end{tabular}

a. Predictors: (Constant), $\mathrm{x} 2, \mathrm{x} 1$

Berdasarkan hasil uji $R$ square, nilai

berpengaruh sebesar $21,5 \%$ terhadap

dari Adjusted $R$ Square pada penelitian, yaitu 0,215. Dari nilai tersebut dapat disimpulkan bahwa variabel kesadaran wajib pajak dan variabel kepatuhan wajib pajak. pengetahuan wajib pajak hanya

\section{SIMPULAN DAN SARAN}

1. Kesadaran Wajib Pajak secara partial berpengaruh positif namun tidak signifikan terhadap Kepatuhan Wajib Pajak dalam membayar kewajiban pajak kendaraan bermotor.

2. Pengetahuan wajib pajak secara partial berpengaruh positif namun tidak signifikan terhadap Kepatuhan Wajib Pajak dalam membayar kewajiban pajak kendaraan bermotor.

3. Kesadaran wajib pajak dan pengetahuan wajib pajak secara simultan berpengaruh signifikan

terhadap kepatuhan wajib pajak dalam membayar kewajiban perpajakan bermotor. Serta saran yang dapat diberikan oleh peneliti berdasarkan hasil penelitian dan terkait variabel yang diteliti ialah:

4. Bagi Instansi pajak terutama Badan Pajak dan Retribusi Daerah (BPRD) Jakarta dan kantor bersama Samsat

5. Jakarta dapat menggunakan penelitian ini sebagai bahan evaluasi bahwa instansi pajak dapat melakukan pendekatan atas kesadaran wajib pajak dan pengetahuan wajib pajak secara bersamaan dalam hal melakukan penyuluhan 
kepada wajib pajak agar

dapat mengurangi jumlah

wajib pajak yang tidak

melaksanakan kewajiban atas

pajak kendaraan bermotor

dan bagi peneliti selanjutnya

agar menambah variabel

independen maupun

pernyataan-pernyataan

dalam pembuatan kuesioner yang memiliki keterkaitannya

dengan variabel penelitian

serta menambah jumlah

sampel penelitian agar

memudahkan dalam

melakukan pengolahan data.

\section{DAFTAR PUSTAKA}

Dewi, N. (2019). Pentingnya

Kesadaran dalam Membayar

Pajak. Pentingnya Kesadaran

Dalam Membayar Pajak.

Peraturan Daerah Provinsi Daerah

Khusus Ibukota Jakarta, Pub. L.

No. 2 (2015).

Hayatina. (2019, September).

Waduh! 4,9 Juta Kendaraan di

DKI Nunggak Pajak Rp 2,1 T.

Detik Finance.

Undang-Undang Republik Indonesia

Nomor 32 Tahun 2004 Tentang
Pemerintahan Daerah, Pub. L. No. 32 (2004).

Sarjono \& Julianita. (2011). SPSS vs LISREL: Sebuah Pengantar, Aplikasi untuk Riset. Salemba Empat.

Sugiyono. (2013). Metode Penelitian Kuantitatif, Kualitatif dan $R \& D$. Alfabeta.

Undang-Undang Republik Indonesia Nomor 28, Pub. L. No. 28 (2007). 